\title{
PRACTICE OF PARALLEL IMPORTING: PROTECTION OF INTERNATIONAL COMPANIES' TRADEMARKS RIGHTS IN RUSSIAN FOREIGN TRADE
}

\author{
Victor Kovalev, ${ }^{1}$ Oksana Falchenko, ${ }^{2}$ Veronika Vyazovskaya, ${ }^{3}$ Alexander $\operatorname{Semin}^{4}$
}

\begin{abstract}
The paper is devoted to the problem of the exhaustion of international companies' trademarks and other intellectual property objects rights in the foreign trade practices of Russia and other countries of the Eurasian Economic Union (EEU). The paper focuses on the problems of trade integration through the intellectual property market, since any free movement of goods should always be correlated with respect for the interests of the trademark rights owners. The aim of this paper is to explore the process of parallel importing in the aspect of international companies trademarks intellectual property rights in the Russian Federation and EEU countries and the opportunities and challenges it provides for both manufacturers and importers. The problem of importing products labeled with trademarks through parallel import channels to Russia is being considered using the schemes for the importation of counterfeit goods into Russia through EEU countries. The analysis shows that there are the problems with the application of the mechanisms of trademarks customs protection in practice. The main problem is the lack of unified legislation for intellectual property protection in EEU members.
\end{abstract}

JEL Classification Numbers: F10, F15, F23, O34; DOI: http://dx.doi.org/10.12955/cbup.v5.932

UDC Classification: $339.5,339.9$

Keywords: parallel imports, intellectual property, trademark, international company

\section{Introduction}

With the creation of the Customs Union, the Common Economic Space, and then the Eurasian Economic Union (EEU), the issues of intellectual property protection in the member countries are becoming more urgent, as the development of integration processes intensifies the consolidated movement of goods between business entities located on the territory of the EEU member states. Any free movement of goods must always be correlated with observance of the interests of the trademark rights owners. This problem did not bypass the trade of the EEU countries, in the first place this problem affected the interests of international producers in the food, automotive and pharmaceutical industries. The purpose of this paper is to explore the process of parallel importing in the aspect of international companies trademarks intellectual property rights in the Russian Federation and EEU countries and the opportunities and challenges it provides for both manufacturers and importers.

\section{Parallel importing: literature review}

This section offers a short summary of the literature on parallel imports. Parallel importing (or gray marketing) has been a widespread international practice, and one of concern to international manufacturers, distributors and retailers since the mid 1980s up to the present time (e.g. Baldo, 1985; Barlass, 1988; Mitchell, 1998). When gray marketing occurs across markets, such as in an international setting, the term used most commonly is 'parallel importing'. According to Duhan and Sheffet (1998), "gray" may imply an "almost black market." These points of view are very important for us because they can help to present in this article some possible schemes for the importation of counterfeit goods into Russia through the countries of the Eurasian Economic Union (creation of a new "gray" or an "almost black market" in EEU).

According to Maskus (2001), parallel importing means that the trade situation which involve genuine products that are produced under patent, copyright or a trademark protection, which are imported into another market (the destination market), without appropriate authorization of the intellectual property owner in the destination market. Parallel trade refers to the resale of goods between countries without the authorization of the intellectual property rights owner associated with those goods (Kyle, 2009). Parallel importing involves the selling of trademarked goods through channels of distribution that are not authorized by the trademark holders (Duhan \& Sheffet, 1988). Mathur (1995) estimated the size of international parallel markets - from \$US7 billion to \$US10 billion. Parallel imports affect a wide range of industries, spreading from traditional luxury and brand name consumer products to industrial ones.

\footnotetext{
${ }^{1}$ Ural State University of Economics, kovalev@usue.ru

${ }^{2}$ Ural State University of Economics, falchenko@usue.ru

${ }^{3}$ Ural State University of Economics, veronika.vyazovskaya@ gmail.com

${ }^{4}$ Global Economy Institute, Ural State Mountain University, aleks_ural_55@mail.ru
} 
In the academic literature, we can find different points of view on parallel importing. The literature debates centre on whether parallel importing is a legitimate response to discriminatory pricing strategies or a market failure that occurs when business entities take advantage of being able to use a common resource, or collective good, without paying for it (see, e.g. Malueg \& Schwartz, 1994; Kitchen et al., 2003).

In this paper, it is very important to use the opinions of foreign researchers about parallel importing issues. In Russia and the EEU this problem is quite new and the justification of our conclusions in this article will be quite weak without reference to the above authors.

Parallel trade deals with topics in three related fields: intellectual property law, international trade, and competition law (Kyle, 2009). The economics of parallel import can be viewed from the pricing and legislative perspectives. The first driving force for parallel imports is legislation. According to World Trade Organization (WTO) Agreement on Trade-Related Aspects of Intellectual Property Rights (TRIPS Agreement) there are three forms of exhaustion of intellectual property rights (see also, Abbot, 2007; Semin et al., 2016):

1. national exhaustion principle (refers to exhaustion of the intellectual property owner's rights on the first authorized sale in the specified national territory, while the patent owner may continue to enforce his rights in the region other than the defined national territory based on the legislation adopted by the other region);

2. regional exhaustion principle (refers to exhaustion of the intellectual property owner's rights in a specific region, for instance the Eurasian Economic Union, etc..., and its member states, while the intellectual property owner continues the right to distribution of the product anywhere outside the region);

3. international exhaustion principle (refers to exhaustion of the intellectual property owner's rights to the product across all the geographies, irrespective of the territory of the first authorized sale).

According to WTO's documents (see, e.g. The Doha Conference 2001 (WT/MIN(01)/DECW/2, 2001), paragraph 5(d)), the WTO members are free to choose the exhaustion regime without challenge, provided the clauses of MFN and National Treatment are complied with. The ability of the intellectual property owner to restrict such movement depends on the exhaustion regime followed by the destination country. Thus, in an increasingly integrated world, the annual growth rate of parallel imports has been estimated to be $22 \%$, and this is expected to rise as new trade agreements, like GATT, TRIPS, etc., further lower trade barriers across nations (Skoko, 2014).

The second driving force for parallel imports is the price discrimination of the same product across different geographies when a firm sets a different price for the same product for different groups of customers based on the region, demographics, or any such segmentation, as defined in elementary economics (Hirschey, 2009). Skoko (2014) writes, that there are two reasons why parallel imports occur in international markets. Firstly, the parallel import exists because foreign manufacturers practice price discrimination among countries and gray market sellers arbitrage these price differences. Secondly, parallel importers are more efficient than authorized sellers because parallel imports compete with the goods of authorized sellers, in turn leading to lower prices that are beneficial to consumers.

\section{Parallel importing in the Eurasian Economic Union: contradictions and Russian experience}

In the EEU countries, there are different principles of exhaustion of exclusive rights to trademarks and other objects of intellectual property. So, in Russia, Belarus and Kyrgyzstan, there is a territorial (national) principle of exhaustion of rights to intellectual property objects, which means that the right to import original goods from other countries into the country belongs to either the right holder or his official distributor. It is very important, that there is an international principle of the exhaustion of rights in Kazakhstan and Armenia, which assumes that the exclusive right of the right holder is deemed to be exhausted with respect to a particular commodity at the time of its first introduction into commercial circulation in any EEU country. Thus, the commercial movement of goods between EEU countries is almost not limited.

There is a regional principle between the EEU countries - free movement between states, which does not violate the exclusive right to a trademark to use this trademark in respect of goods that have been lawfully introduced into civil circulation in the territory of the EEU directly by the right holder or other persons with his consent. In accordance with the Customs Code of the EEU, those intellectual 
property objects that are entered by the right holder in the single EEU customs register of intellectual property objects (ETROIS) or the national (Russian, Kazakh, Belarusian, Armenian, Kyrgyz) customs registers of intellectual property objects (TROIS) are subject to protection. It should be emphasized that to date, the main problem has not been resolved - the harmonization of national legislations with regard to the protection of intellectual property. This illustrates the fact that currently there are no registered intellectual property objects in the ETROIS.

In parallel with the ETROIS, the customs authorities of the EEU member countries maintain national customs registers of intellectual property (TROIS). However, the filling of these registers varies: as of March-April 2016, there were 3864 objects (trademarks) registered in Russia, in Kazakhstan - 605, in Belarus - 293, in Armenia - 174, in Kirghizia - 148. For example, through the use of Russian TROIS, its interests are protected as foreign producers of food and beverages: Unilever NV (trademarks RAMA, BERTOLLI, etc.), Nestle Food LLC (trademarks MAGGI, NESQUIK, etc.), the company Ferrero SpA." ("Ferrero SpA") (trademarks (KINDER BUENO, Kinder Chocolate, Ferrero, Nutella, etc.), Kraft Foods Deutschland Holding GmbH (trademarks "Jacobs" et al ), Jack Daniel's Properties, Inc. (JACK DANIEL'S trademark), and others. At the same time, there is a problem that undermines the effectiveness of the national TROIS, consisting in the fact that, due to the difference in their filling, there is the possibility of unimpeded importation of goods containing intellectual property to the territory of one of the states in which they are not protected by rights holders, and taking into account the absence of internal customs borders for their further distribution in the territory of other EEU countries. We will consider the possible schemes for the import of counterfeit goods into the territory of Russia, which will be legal from the point of view of the legislation of the EEU (Table 1).

Table 1: Possible schemes for the importation of counterfeit goods into Russia through the countries of the Eurasian Economic Union

\begin{tabular}{|c|c|}
\hline The essence of the scheme & $\begin{array}{ll} & \text { Schema content } \\
\end{array}$ \\
\hline $\begin{array}{l}\text { 1) Scheme of import of "gray" } \\
\text { goods to Russia, realized in } \\
\text { connection with the difference in } \\
\text { the principles of exhaustion of } \\
\text { rights in the countries of the } \\
\text { Eurasian Economic Union }\end{array}$ & $\begin{array}{l}\text { There is the National (territorial) principle of exhaustion of rights in Russia, } \\
\text { Belarus and Kyrgyzstan, while in Kazakhstan and Armenia it is } \\
\text { international. According to this scheme, it is possible to import goods to } \\
\text { Russia through the customs border of Kazakhstan or Armenia, where the } \\
\text { exclusive right of the right holder is deemed to be exhausted after the } \\
\text { introduction of a specific commodity into circulation in any country, and } \\
\text { due to unimpeded movement within the EEU, the goods can be delivered to } \\
\text { Russia. For Russia, these goods have the status of counterfeit (if they are not } \\
\text { supplied by official distributors), but according to the legislation of the } \\
\text { EEU, these are legal goods. }\end{array}$ \\
\hline $\begin{array}{l}\text { 2) Scheme of the importation of } \\
\text { illegal goods into Russia due to } \\
\text { differences in the lists of } \\
\text { controlled objects of intellectual } \\
\text { property (TROIS) throughout the } \\
\text { customs border }\end{array}$ & $\begin{array}{l}\text { The scheme enables the import of counterfeit goods through the territory of } \\
\text { the country where the objects of intellectual property are not subject to } \\
\text { customs protection (the difference in the filling national TROIS): } \\
\text { A) Import of goods into Russia through the territory of the Republic of } \\
\text { Belarus or Kyrgyzstan (provided that the intellectual property object is not } \\
\text { included in the TROIS of Belarus / Kyrgyzstan). In Belarus and Kyrgyzstan, } \\
\text { the ex officio principle does not apply, customs authorities do not check } \\
\text { goods not included in the TROIS; } \\
\text { B) Import of goods into Russia through the territory of Kazakhstan, but one } \\
\text { should take into account the possibility of applying the ex officio principle } \\
\text { in force there, which allows customs authorities to detain counterfeit goods, } \\
\text { even if they were not included in the national TROIS. }\end{array}$ \\
\hline
\end{tabular}

Most of the goods imported to Russia contain objects of intellectual property. This fact especially refers to the well-known international companies' goods imported to Russia and other EEU members from different countries. Analysing the Russian Federation customs bodies activity, we can see the number of intellectual property objects in the customs register (TROIS) increased by $24.4 \%$ in 2015 compared to 2013, from 3053 units up to 3860 units (Table 2). 304 units of intellectual property were included into the customs register in 2015. For the period 2013-2015 customs authorities prevented the damage of 10.3 billion rubles that could have been caused to the property right holders. In 2015 customs authorities identified 18.1 million units of counterfeit goods, and their share almost doubled in comparison with 2014, which may be partly due to the 
problem of foreign trade sanctions. In 2015 customs authorities instituted 1121 proceedings in cases concerning administrative offenses. 96-97\% of these proceedings - the article "illegal use of a trademark."

Table 2: The main indicators of the intellectual property rights protection realized by the customs authorities of Russian Federation in 2013-2015

\begin{tabular}{|l|l|c|c|c|}
\hline № & \multicolumn{1}{|c|}{ Indicator } & \multicolumn{1}{|c|}{2013} & 2014 & 2015 \\
\hline 1 & $\begin{array}{l}\text { Number of intellectual property objects in the customs register, end -of -year units, } \\
\text { including: } \\
\text { intellectual property objects included in the customs register, units }\end{array}$ & 3053 & 3556 & 3860 \\
\hline 2 & Prevented damage to the intellectual property right holders, billion rubles & 457 & 503 & 304 \\
\hline 3 & Identified counterfeit products, million units. & 5 & 2.4 & 3.9 \\
\hline 4 & $\begin{array}{l}\text { Number of proceedings in cases concerning administrative offenses, including:: } \\
\text { "illegal use of a trademark"- art. 14.10 of the Administrative Code }\end{array}$ & 1188 & 9.5 & 18.1 \\
\hline & "violation of copyright and related rights "- part 1 art.7.12 of the Administrative Code & 33 & 36 & 1121 \\
\end{tabular}

Source: Author

The analysis of judicial practice shows that the actors of parallel imports in certain cases are brought to:

1. administrative liability (for illegal use of a trademark). For example, the Arbitration Court of Sverdlovsk Region in its Judgment of 10 June 2014, upheld by the order of the Seventeenth Arbitration Appeal Court of 15 August 2014, brought the closed joint-stock company "Imcom" to administrative liability under article 14.10, part 1 of the Russian Administrative Code and sentenced it to administrative fine of 30,000 rubles and confiscation of the items containing illegal reproduction of a trademark "Barbie", seized with the protocol of seizure of 16 January 2014 in the Customs of Yekaterinburg;

2. civil liability (compensation to official distributors on the territory of Russia). The table below shows examples of compensation payments to official distributors on the territory of Russia (Table 3).

Table 3: Amounts of compensation for illegal use of trademarks

\begin{tabular}{|c|c|}
\hline \multicolumn{2}{|c|}{ Examples of judicial practice } \\
\hline $\begin{array}{l}\text { A RECORD HIGH AMOUNT OF COMPENSATION } \\
\text { FOR ILLEGAL USE OF TRADEMARK }\end{array}$ & $\begin{array}{l}\text { A RECORD } L O W \text { AMOUNT OF COMPENSATION } \\
\text { FOR ILLEGAL USE OF TRADEMARK }\end{array}$ \\
\hline $\begin{array}{l}1.5 \text { mln rubles (charged in total) for illegal use of a } \\
\text { trademark «Abbott.» } \\
\text { Judicial ground: Order of the West Siberian District FAS } \\
\text { of } 14 \text { February } 2013 \text { in the case № A } 45-5005 / 12 \text { (the } \\
\text { Supreme Arbitration Court of Russian Federation in its } \\
\text { Definition of } 05 \text { June } 2013 \text { № BAC-6633/13 refused to } \\
\text { refer the case to the Supreme Arbitration Court Presidium } \\
\text { for supervisory review). }\end{array}$ & $\begin{array}{l}\text { The legal owner of a medical equipment trademark } \\
\text { «ACCU-CHEK» demanded an importer to pay } \\
\text { compensation of 20,000 rubles. } \\
\text { Judicial ground: Order of a Court for Intellectual Property } \\
\text { Rights of 19June } 2014 \text { in the case № A76-17672/2013. }\end{array}$ \\
\hline $\begin{array}{l}2.1 \text { mln rubles for illegal use of trademarks «Guinness» } \\
\text { and «Merries» (single case). } \\
\text { Judicial ground: Order of the Moscow region FAS of } 18 \\
\text { June } 2012 \text { in the case № A40-78553/11-110-648 (the } \\
\text { Supreme Arbitration Court of Russian Federation in its } \\
\text { Definition of 08 August } 2012 \text { № BAC-681/12 refused to } \\
\text { refer the case to the Supreme Arbitration Court Presidium } \\
\text { for supervisory review). }\end{array}$ & $\begin{array}{l}\text { A Court reduced the amount of compensation to the legal } \\
\text { owner of a trademark «KRUSOVICE» from } 1 \text { mln rubles to } \\
30,000 \text { rubles (10,000 rubles for each violation; } 100 \\
\text { originally labelled bottles were imported). } \\
\text { Judicial ground: Order of the Arbitration Court of Moscow } \\
\text { district of } 25 \text { February } 2013 \text { in the case № A40-23850/12- } \\
27-216 \text {. }\end{array}$ \\
\hline $\begin{array}{l}2.5 \text { mln rubles in favour of each of the plaintiffs for a sale } \\
\text { offer of the original watches on the territory of Russia. A } \\
\text { Court has satisfied the requirements of the companies- } \\
\text { owners of trademarks "LONGINES," "OMEGA," "RADO" } \\
\text { about compensation, but less than the declared amount. } \\
\text { Judicial ground: the Supreme Arbitration Court of Russian } \\
\text { Federation in its Definition of } 15 \text { July } 2014 \text { No BAC- } \\
12583 / 13 \text { refused to refer the case to the Supreme } \\
\text { Arbitration Court Presidium }\end{array}$ & $\begin{array}{l}\text { A Court reduced the amount of compensation from } 400,000 \\
\text { rubles to 200,000 rubles and from } 1 \text { mln rubles to } 30,000 \\
\text { rubles in the cases of Heinrken Ceska republika. } \\
\text { Judicial ground: Order of the Moscow region FAS of } 16 \\
\text { April } 2012 \text { in the case №A40-51953/11-51-440, and Order } \\
\text { of } 25 \text { February } 2013 \text { in the case №A40-23850/12-27-216. }\end{array}$ \\
\hline
\end{tabular}

3. criminal liability (for the illegal use of a trademark repeatedly or by causing large-scale damage). For example, in the case of the illegal use of a trademark «Creative,» the guilty person was brought to criminal liability for entering into civil circulation of the original goods (Definition of a Sverdlovsk Regional Court of 25 November 2009 in the case №22-110966). 
To date, the issues relating to the administrative liability and compensation to the trademarks rights holders in arbitration courts are most relevant. The analysis of Russian judicial practice permits to single out two approaches to parallel importing: when parallel imports are an independent illegal way of using a trademark and when parallel imports do not violate the exclusive rights of the right holder. In the first case, when parallel import is an independent illegal way of using a trademark, the import of both counterfeit and original goods to Russia with the independent use of a trademark without the consent of the right holder is an illegal way of using a trademark, that is a violation of exclusive rights to the trademark. Thus, the Arbitration Court of Moscow in its Judgment of 02 June 2011 in the case № A40-12515/11, recognized illegal the Ltd. "ElitVoda Ru" import of goods (mineral water) labelled «S.PELLEGRINO» to the territory of Russia; ordered to seize and eliminate the goods labelled «S.PELLEGRINO.»In the second case, when parallel imports do not violate the exclusive rights of the right holder, the main purpose of a trademark is to provide a potential consumer the opportunity to distinguish goods produced by one person from similar goods produced by other persons. It is a customer loyalty issue and when some similar design of trade mark cannot mislead consumers to choose these similar goods but not the right holder's goods, hence, there is no place for applying the trademark rights protection. This approach was used in a case with the claim of the company KAYABA KOGYO KABUSHIKI KAISHA to Ltd. «Avtologuistika» (Definition of the Ninth Russian Arbitration Court of Appeal of 28 September 2009 in the case № A40-2250/09-51-27).

\section{Conclusion}

In conclusion, it should be noted that the problem of protecting intellectual property rights for producers' trademarks is quite acute in Russia, despite significant steps to improve the legislative base of the Russian Federation and the EEU. The problem of delimitation of the counterfeit and original products importation is especially urgent. Specialists on the protection of the trademark from parallel imports distinguish three main ways of such protection: the information introduction in the customs registers of intellectual property objects in order to suspend the release of goods; appealing to the court, including with the claim of recognizing the parallel importer actions as unfair competition; and attracting a parallel importer to criminal liability.

\section{References}

Abbot, F. M. (2007). Parallel Importation: Economic and social welfare dimensions. Manitoba: International Institute for Sustainable Development (IISD).

Baldo, A. (1985). Score one for the grey market. Forbes, 135 (4), February 25, 4.

Barlass, S. (1988). Grey marketing war escalates. Marketing News, 26 September, 8 - 9.

Dmitriyev, V. (2013) Effektivnyye sredstva zashchity ot parallel'nogo importa [Effective protection against parallel import]. Korporativnyy yurist. Praktikum. [Corporate lawyer. Workshop], Retrieved March, 10, 2017, from http://www.clj.ru/journal/288/5009/

Duhan, D.F., \& Sheffert, M.J. (1988, July). Grey markets and the legal status of parallel importing. Journal of Marketing, 52 , $75-83$.

Hirschey, M. (2009). Managerial Economics. Mason, Ohio: Cengage Learning.

Kitchen, P. J., \& Eagle, L., \& Rose, L. C., \& Moyle, B. J. (2003) The impact of grey marketing and parallel importing on brand equity and brand value. Research Memorandum, 38. UK: The University of Hull Business School. Retrieved March, 10, 2017, from http://www2.hull.ac.uk/hubs/pdf/memorandum38.pdf

Kyle, M. K. (2009). Parallel Trade in Pharmaceuticals: Firm Responses and Competition Policy, Ch.13, in B.E. Hawk, International Antitrust Law \& Policy: Fordham Competition Law 2009. New York: Juris Publishing. Retrieved March, 10, 2017, from http://www.margaretkyle.net/IntlAntitrust.pdf

Malueg, D.A., \& Schwartz, M. (1994). Parallel imports, demand dispersion and international price discrimination. Journal of International Economics, 37, 167 - 195. Retrieved March, 10, 2017, from http://dx.doi.org/10.1016/0022-1996(94)90044-2 Maskus, K. E. (2001, April). Parallel imports in pharmaceuticals: implications for competition and prices in developing countries. Geneva: World Intellectual Property Organization. Retrieved from http://www.wipo.int/export/sites/www/aboutip/en/studies/pdf/ssa_maskus_pi.pdf

Mathur, L.M. (1995). The impact of international grey marketing on consumers and firms. Journal of Euro-marketing, 4 (2), $39-59$.

Mitchell, A. (1998). Customer rights a grey area in distribution ban. Marketing Week, July 23, 30 - 31.

Semin, A.N., \& Kovalev, V.E., \& Falchenko, O.D. (2016). Vzaimodeystviye ekonomik stran YEAES v torgovle tovarami pishchevoy promyshlennosti: problemy integratsii cherez rynok intellektual'noy sobstvennosti [The Interaction of the Economies of the EAEU state-members in the trade of food industry goods: problems of integration through intellectual property market], Ekonomika sel'skokhozyaystvennykh i pererabatyvayushchikh predpriyatiy [Economics of Agricultural and Processing Enterprises], 8, 10-17.

Skoko, H. (2014, March 17). Theory and practice of parallel imports. Working paper, Bathurst, Australia: Charles Sturt University. Retrieved March, 10, 2017, from

https://www.researchgate.net/publication/242138009_theory_and_practice_of_parallel_imports_the_new 